\title{
RULES GOVERNING COMPETITION WITHIN THE EUROPEAN REGIONAL COMMUNITIES**
}

\author{
Jochen ThIESING $\dagger$
}

\section{INTRODUCTION}

It is necessary to refer to the European Communities in the plural because the six European countries (Belgium, the Federal Republic of Germany, France, Italy, Luxembourg, and the Netherlands) that have united in these Communities have, by three separate Treaties, established three Communities, each of which is endowed with its own legal personality. ' The six Member States took the first step in I95I, when they established the European Coal and Steel Community (E.C.S.C.). ${ }^{2}$ They proceeded further by concluding the Treaties establishing the European Economic Community (E.E.C.) ${ }^{3}$ and the European Atomic Energy Community (Euratom) ${ }^{4}$ in 1957 .

Though the three Communities are three separate legal entities, they are, nonetheless, linked to one another in various ways, both legally and in practice. Under the Convention on the Joint Institutions of the European Communities, ${ }^{5}$ which came into force simultaneously with the Treaties on January $I$, 1958, the powers of the Parliament and the competence of the Court of Justice-for which provision is made in the three Treaties-are exercised by a single European Parliamentary Assembly and a single Court of Justice, which has its seat in Luxembourg. Moreover, a single Economic and Social Committee, composed of representatives from the various

- Translated from the German by R. Lederer. The views expressed in this article are those of the writer and do not necessarily reflect those of the Commission of the European Economic Community. †Attorney in Berlin, Germany, since 1939. Chief of bureau in Federal Ministry of Economics, Bonn, for matters of deconcentration since 1950, and legal problems of the European Coal and Stcel Community since r954. Legal Adviser, Commission of the European Economic Community, Brussels, since 1958 .

${ }^{1}$ E.C.S.C. Treaty art. 6; E.E.C. Treaty art. 2ro; Euratom Treaty art. 184 .

2 The E.C.S.C. Treaty of April 18, 1951, came into force on July 23, 1952; only the French text of the Treaty is authentic E.C.S.C. Treaty art. yoo. See generally Paul Reuter, LA Communaute Europíenne du Charbon et de l'Acier (i953); Franz Jerusalea, Das Recht der Montanunion (I954); William Diebold, The Schuman Pean: A Study in Economic Cooperation ig50-59 (1959).

${ }_{3}$ The Treaty of March 25, I957, came into force on Jan. I, 1958. Like the Euratom Treaty, it was drawn up in the four official languages of the Community (German, French, Italian, and Dutch), all four texts being equally authentic. E.E.C. Treaty art. 248; Euratom Treaty art. 225. The texts of the two Treaties were published in the four official languages in [1957] 2 Bundesgesetzblatt 753 (Ger. Fed. Rep.). The Secretariat of the Interim Committee for the Common Market and Euratom has published an unofficial English translation. See generally Nicola Catalano, La Communità Economica Europa e Euratom (2d ed. 1959); Hans von der Groeben \& Hans von BoeckH (Eds)., Handduch pür. EURopäısche Wirtschaft (1958, 1960); ErNst WoHLFarth et aL., Die EURopäische Wirtschaftsgemeinschaft (1960); I and 2 Eric Stein \& Thomas L. Nicholson (Eds.), AMerican Entemprise in the European Common Market: a Legal Profile (rg60).

4 The Treaty of March 25, 1957, came into force on Jan. I, 1958. For further details, see supra note 3; sce also Jacques Errera et al., Euratom, Anslyse et Commentaires du Traite (x958).

${ }^{5}$ Of March 25, 1957. [r957] 2 Bundesgesetzblatt I156 (Ger. Fed. Rep.) 
spheres of economic and social life, ${ }^{6}$ advises both the Commission of E.E.C. and that of Euratom. The three Communities have a joint Legal Service, a joint Statistical Office, and a joint Press and Information Service.

The Council, which in all three Communities consists of representatives of the Governments of the Member States, ${ }^{7}$ is frequently composed of the same persons for the three Communities, responsible as members of their Government for the various affairs of the Communities. Further, the Commissions of the E.E.C. and of Euratom and the High Authority, the executive organ of the E.C.S.C., have in 1958 and 1959 set up interexecutive groups of the three Communities to deal with the following issues: external relations, energy policy, social affairs, transport problems, press and information, statistics, and interexecutive co-operation. ${ }^{8}$ The scope of this paper does not require any detailed examination of the provisions of the Euratom Treaty. It is the function of Euratom to contribute to raising the standard of living in the Member States and to develop relations with other States by creating the conditions necessary for the speedy establishment and evolution of nuclear industries. ${ }^{.}$In particular, the supply of all Member States with ores, basic materials, and fissionable materials is to be ensured on the principle of equal access to resources by means of a common supply policy. ${ }^{10}$ Apart from this broad principle, the Euratom Treaty does not contain any real rules on competition.

The E.C.S.C. Treaty's rules on competition are laid down in its articles sixtyfive ${ }^{11}$ and sixty-six. ${ }^{12}$ These provisions apply only to coal- and steel-producing enter-

- E.E.C. Treaty art. 193; Euratom Treaty art. 165.

${ }^{7}$ E.C.S.C. Treaty art. 27 ; E.E.C. Treaty art. 146 ; Euratom Treaty art. 116.

${ }^{8}$ Cf. Euratom Commission, Third General Report I45 (German version) and II5 (French version) (r960). Even wider proposals on the cooperation between the three executives are under consideration.

${ }^{0}$ Euratom Treaty art. $I$.

${ }^{10}$ Id. art. 52.

${ }^{11}$ Art. 65:

I. There are hereby forbidden all agreements among enterprises, all decisions of associations of enterprises, and all concerted practices, which would tend, directly or indirectly, to prevent, restrict or distort the normal operation of competition within the common market, and in particular:

(a) to fix or infuence prices;

(b) to restrict or control production, technical development or investments;

(c) to allocate markets, products, customers or sources of supply.

2. However, the High Authority will authorize enterprises to agree among themselves to specialize in the production of, or to engage in joint buying or selling of specified products, if the High Authority finds:

(a) that such specialization or such joint buying or selling will contribute to a substantial improvement in the production or marketing of the products in question; and

(b) that the agreement in question is essential to achieve such effects, and does not impose any restriction not necessary for that purpose; and

(c) that it is not susceptible of giving the interested enterprises the power to infuence prices, or to control or limit production or marketing of an appreciable part of the products in question within the common market, or of protecting them from effective competition by other enterprises within the common market.

If the High Authority should recognize that certain agreements are strictly analogous in their nature and effects to the agreements mentioned above, taking into account the application of the present section to distributing enterprises, it will authorize such agreements if it further recognizes that they satisfy the same conditions.

An authorization may be made subject to specified conditions and may be limited in time. If so 
limited, the High Authority will renew it once or several times if it finds that at the time of renewal the conditions stated in paragraph (a) to (c) above are still fulfilled.

The High Authority will revoke or modify the authorization if it finds that as a result of changes in circumstances the agreement no longer fulfills the conditions set forth above, or that the actual effects of the agreement or of the operations under it are contrary to the conditions required for its approval.

The decisions granting, modifying, refusing or revoking an authorization shall be published along with their justification; the limitations contained in the second paragraph of Article 47 shall not be applicable to such publication.

3. The High Authority may obtain, in accordance with the provisions of Article 47, any information necessary to the application of the present article, either by a special request addressed to the interested parties or by a regulation defining the nature of the agreements, decisions or practices which must be communicated to it.

4. Any agreement or decision which is prohibited by virtue of Section I of the present article shall be automatically void and may not be invoked before any court or tribunal of the member States.

The High Authority has exclusive competence, subject to appeals to the Court, to rule on the conformity of such agreements or decisions with the provisions of the present article.

5. The High Authority may pronounce against enterprises:

which have concluded an agreement which is automatically void;

which have complied with, enforced or attempted to enforce by arbitration, forfeiture, boycott or any other means, an agreement or decision' which is automatically void or an agreement for which approval has been refused or revoked;

which shall have obtained an authorization by means of knowingly false or misleading information; or

which engage in practices contrary to the provisions of Section $x$, fines and daily penalty payments not to exceed double the turnover actually realized on the products which have been the subject of the agreement, decision or practice contrary to the provisions of the present article; if the object of the agreement is to restrict production, technical development or investments, this maximum may be raised to ro percent of the annual turnover of the enterprises in question, in the case of fines, and 20 percent of the daily turnover in the case of daily penalty payments.

See Robert Krawielicki, Das Monopolverbot im Schuman-Plan (1952); Hans-Worfram Daig, Verbot und Genehmigung für Kartelle nach Art. 65 des Montan-Vertrags (1957).

12. Art. 66:

x. Except as provided in paragraph 3 below, any transaction which would have in itself the direct or indirect effect of bringing about a concentration, within the territories mentioned in the first paragraph of Article 79, involving enterprises at least one of which falls under the application of Article 80, shall be submitted to a prior authorization of the High Authority. This obligation shall be effective whether the operation in question is carried out by a person or an enterprise, or a group of persons or enterprises, whether it concerns a single product or different products, whether it is effected by merger, acquisition of shares or assets, loan, contract, or any other means of control. For the application of the above provisions, the High Authority will define by a regulation, established after consultation with the Council, what constitutes control of an enterprise.

2. The High Authority will grant the authorization referred to in the preceding paragraph if it finds that the transaction in question will not give to the interested persons or enterprises, as concerns those of the products in question which are subject to its jurisdiction, the power:

-to influence prices, to control or restrain production or marketing, or to impair the maintenance of effective competition in a substantial part of the market for such products; or

- to evade the rules of competition resulting from the application of the present Treaty, particularly by establishing an artificially privileged position involving a material advantage in access to supplies or markets.

In this appreciation, and in accordance with the principle of non-discrimination set forth in subparagraph (b) of Article 4, the High Authority will take account of the size of enterprises of the same nature existing in the Community, to the extent it deems justified to avoid or correct the disadvantages resulting from an inequality in the conditions of competition:

The High Authority may subject such an authorization to any conditions which it deems appropriate for the purposes of the present section.

Before taking action on a transaction concerning enterprises of which at least one is not subject to the application of Article 8o, the High Authority will request the observations of the interested government.

3. The High Authority will exempt from the requirement of prior authorization those classes of transactions which, by the size of the assets or enterprises which they affect taken together with the nature of the concentration they bring about, must in its opinion be held to conform to the conditions 
required by Section 2. The regulation established for this purpose with the concurrence of the Council will also fix the conditions to which such exemption is to be subject.

4. Without limiting the applicability of the provisions of Article 47 to enterprises subject to its jurisdiction, the High Authority may obtain from physical or juridical persons who have acquired or regrouped or might acquire or regroup the rights or assets in question, any information necessary to the application of the present article concerning operations which might produce the effect mentioned in Section I; it may do this either by a regulation established after consultation with the Council which defines the nature of the operations which must be communicated to it, or by a special demand addressed to the interested parties within the framework of such regulation.

5. If a concentration should occur, which the High Authority finds has been effected contrary to the provisions of Section I but which it finds nevertheless satisfies the conditions provided in Section 2, it will subject the approval of this concentration to the payment, by the persons who have acquired or regrouped the rights or assets in question, of the fine provided in the second sub-paragraph of Section 6; such payment shall not be less than half of the maximum provided in the said sub-paragraph in any case where it is clear that the authorization should have been requested. In the absence of this payment, the High Authority will apply the measures provided hereafter for concentrations found to be illegal.

If a concentration should occur which the High Authority recognizes cannot satisfy the general or special conditions to which an authorization under Section 2 would be subject, it will establish the illegal character of this concentration by a decision accompanied by a justification; after having allowed the interested parties to present their observations, the High Authority shall order the separation of the enterprises or assets wrongly concentrated or the cessation of common control, as well as any other action which it deems appropriate to re-establish the independent operation of the enterprises or assets in question and to restore normal conditions of competition. Any person directly interested may take an appeal against such decisions under the conditions provided in Article 33. Notwithstanding the provisions of that article, the Court shall be fully competent to judge whether the operation effected is a concentration within the meaning of Section $I$ of the present article and of the regulations issued in application of that section. This appeal shall be suspensive. It may not be taken until the measures provided above have been ordered, unless the High Authority should agree to the taking of a separate appeal against the decision declaring the transaction illegal.

The High Authority may at any time, subject to the possible application of the provisions of the third paragraph of Article 39, take or cause to be taken such measures as it may deem necessary to safeguard the interests of competing enterprises and of third parties, and to prevent any action which might impede the execution of its decisions. Unless the Court decides otherwise, appeals shall not suspend the application of such precautionary measures.

The High Authority will grant to the interested parties a reasonable period in which to execute its decisions, at the expiration of which it may begin to impose daily penalty payments not to exceed one tenth of one percent of the value of the rights or assets in question.

Furthermore, if the interested parties fail to fulfill their obligations, the High Authority shall itself take measures of execution and in particular may: suspend the exercise, in enterprises subject to its jurisdiction, of the rights attached to the assets illegally acquired; bring about the designation by judicial authorities of a receiver-administrator for these assets; organize the forced sale of such assets in conditions preserving the legitimate interests of their proprietors; annul, with respect to physical or juridical persons who have acquired the rights or assets in question by the effect of illegal transaction, the acts, decisions, resolutions, or deliberations of the directing organs of enterprises subject to a control which has been irregularly established.

The High Authority is also empowered to address to the interested member States the recommendations necessary to obtain, within the framework of national legislation, the execution of the measures provided for in the preceding paragraphs.

In the exercise of its powers, the High Authority shall take account of the rights of third persons which have been acquired in good faith.

6. The High Authority may impose fines not to exceed:

-3 percent of the value of the assets acquired or regrouped or to be acquired or regrouped, against physical or juridical persons who shall have violated the obligations provided for in Section 4;

$\rightarrow$ Io percent of the value of the assets acquired or regrouped, against physical or juridical persons which shall have violated the obligation provided for in Section I; after the end of the twelfth month following the transaction, this maximum shall be raised by one-twenty-fourth per month which elapses until the High Authority establishes the existence of the violation;

$\rightarrow$ - o percent of the value of the assets acquired or regrouped or to be acquired or regrouped, against physical or juridical persons which shall have obtained or attempted to obtain the benefit of the provisions of Section 2 by means of false or misleading information; 
prises within the European territories of the Member States, as well as to enterprises or organizations regularly engaged in distribution of products of the coal and steel industries other than sale for domestic consumers or to craft industries. ${ }^{13}$ The terms "coal" and "steel" are defined in annex one to the E.C.S.C. Treaty. The E.E.C. Treaty explicitly specifies ${ }^{14}$ that the provisions of the E.C.S.C. Treaty-especially those concerning the rights and obligations of the Member States, the powers of the institutions of the E.C.S..C., and the functions of the Common Market for coal and steel-shall not be affected by it.

The rules on competition in the E.E.C. Treaty apply to all enterprises that do not fall within the terms of reference of the E.C.S.C. These rules are composed of provisions applicable to enterprises, ${ }^{15}$ provisions on the prohibition of state aids or aids granted by means of state resources that distort or threaten to distort competition by favoring certain enterprises or certain productions, to the extent to which they adversely affect trade between Member States, ${ }^{16}$ and provisions on the prohibition of dumping practices within the Common Market. ${ }^{17}$

Only the provisions concerning enterprises will be considered in detail in this article.

The E.E.C. Treaty stipulates that the Council, acting on a proposal of the Commission and after the Assembly has been consulted, shall lay down any appropriate regulations ${ }^{18}$ or directives, ${ }^{10}$ with a view to the application of the principles set out in articles eighty-five ${ }^{20}$ and eighty-six. ${ }^{21}$ This provision has led to considerable differ-

-I5 percent of the value of the assets acquired or regrouped, against enterprises subject to its jurisdiction which shall have participated in or lent themselves to the realization of transactions contrary to the provisions of the present article.

Persons who are the object of sanction's provided for in the present paragraph may appeal before the Court under the conditions provided for in Article 36.

7. To the extent necessary, the High Authority is empowered to address to public or private cnterprises which, in law or in fact, have or acquire on the market for one of the products subject to its jurisdiction a dominant position which protects them from effective competition in a substantial part of the common market, any recommendations required to prevent the use of such position for purposes contrary to those of the present Treaty. If such recommendations are not fulfilled satisfactorily within a reasonable period, the High Authority will, by decisions taken in consultation with the interested government and under the sanctions provided for in Articles 58, 59 and 64 , fix the prices and conditions of sale to be applied by the enterprise in question, or establish manufacturing or delivery programs to be executed by it.

See Krawielicki, op. cit. supra note I $x$; Peter Kern, Das Recht der UNTERnehmenszusammenschlüsse IN DER MONTANunion (I955); Thiesing, Zusammenschliisse von Unternelmen nach dem MontanVertrag, [1954] BetRIEBs-BERATER 449 [hereinafter cited as BB].

${ }^{13}$ E.C.S.C. Treaty art. 80.

${ }^{14}$ E.E.C. Treaty art. 232.

${ }^{15} \mathrm{Id}$. arts. $85-90$.

${ }^{10}$ Id. arts. $92-94$.

${ }^{17}$ Id. art. 91 .

${ }^{18}$ Under art. $\mathrm{x} 89$, E.E.C. regulations are binding in every respect and directly applicable in each Member State.

${ }^{2 \theta}$ Under art. 189 , E.E.C. directives shall bind any Member State to which they are addressed as to the result to be achieved, while leaving to domestic agenicies a competence as to form and means.

20 Art. 85:

I. The following shall be deemed to be incompatible with the Common Market and shall hereby be prohibited: any agreements between enterprises, any decisions by associations of enterprises and any 
ences of opinion as to whether the prohibitions contained in these articles already constitute effective law or not. It is unfortunately not possible within the scope of this article to go into the details of the various views and arguments adduced to support one opinion or the other. ${ }^{22}$ The main arguments presented in defense of the view that the prohibitions of articles eighty-five and eighty-six cannot be applied until after the entry into effect of the regulations to be issued under article eighty-seven consist of the assertion that the content of articles eighty-five and eighty-six is too vague and needs supplementation through implementing regulations; and further, that the immediate application of the prohibition provisions would be incompatible with general principles of law, as these provisions would thereby be given retroactive effect.

Neither of these arguments is convincing. The two articles under review express the prohibitions more concisely than does the text of the two basic articles of the

concerted practices which are likely to affect trade between Member States and which have as their object or result the prevention, restriction or distortion of competition within the Common Market, in particular those consisting in:

(a) The direct or indirect fixing of purchase or selling prices or of any other trading conditions;

(b) the limitation or control of production, markets, technical development or investment;

(c) market-sharing or the sharing of sources of supply;

(d) the application to parties to transactions of unequal terms in respect of equivalent supplies, thereby placing them at a competitive disadvantage; or

(c) the subjecting of the conclusion of a contract to the acceptance by a party of additional supplies which, either by their nature or according to commercial usage, have no connection' with the subject of such contract.

2. Any agreements or decisions prohibited pursuant to this Article shall be null and void.

3. Nevertheless, the provisions of paragraph I may be declared inapplicable in the case of:

-any agreements or classes of agreements between enterprises,

-any decisions or classes of decisions by asociations of enterprises, and

-any concerted practices or classes of concerted practices which contribute to the improvement of the production or distribution of goods or to the promotion of technical or economic progress while reserving to users an equitable share in the profit resulting therefrom, and which:

(a) neither impose on the enterprises concerned any restrictions not indispensable to the attainment of the above objectives;

(b) nor enable such enterprises to eliminate competition in respect of a substantial proportion of the goods concerned.

For the extensive literature on this article, see ERNST WOHLFARTH ET AL., op. cit. supra note 3, Introductory Remark No. 9 on Articles 85 et seq.; see also George Nebolsine, The European Common Market Rules Governing Competition (ig6o).

21 Art. 86:

To the extent to which trade between any Member States may be affected thereby, action by one or more enterprises to take improper advantage of a dominant position within the Common Market or within a substantial part of it shall be deemed to be incompatible with the Common Market and shall hereby be prohibited.

Such improper practices may, in particular, consist in:

(a) the direct or indirect imposition of any inequitable purchase or selling prices or of any other inequitable trading conditions;

(b) the limitation of production, markets or technical development to the prejudice of consumers;

(c) the application to parties to transactions of unequal terms in respect of equivalent supplies, thereby placing them at a competitive disadvantage; or

(d) the subjecting of the conclusion of a contract to the acceptance, by a party, of additional supplies which, either by their nature or according to commercial usage, have no connection with the subject of such contract.

${ }^{22}$ Cf. vON DER GROEBEN \& VON BOECKH, op. cit. supra note 3, Introductory Remarks 10-12 on Articles 85 et seg.; see also, Nebolsine, op. cit. supra note 20 , at 7,8 . 
Sherman Act, ${ }^{22 a}$ which has given American administrators and courts a sufficient basis for the practical application and development of American antitrust legislation. Also, it is wrong to maintain that the prohibitions would be given retroactive effect; this could be the case only if the prohibition had been expressed in respect of a period prior to the entry into force of the Treaty. There is nothing unusual in certain conduct being forbidden as from the entry into effect of a law. It is, however, frequently desirable in such cases to introduce some transitional arrangement in order to avoid difficulties. Such an arrangement has been made in the E.C.S.C. Treaty. The E.E.C. Treaty does not contain any explicit transition provisions, though these could be introduced by way of implementing regulations under article eighty-seven, ${ }^{23}$ to which reference has already been made. ${ }^{23 a}$

So far as the practical application of the Treaty is concerned, it is right to proceed from the assumption that the prohibition provisions in articles eighty-five and eightysix have, with the entry into force of the Treaty, become immediately applicable law in the Member States. The Commission has repeatedly and officially upheld this view $^{24}$ which has, moreover, found the approval of the government experts of the Member States. ${ }^{25}$

\section{Prohibition of Cartels}

The prohibition provisions in article sixty-five of the E.C.S.C. Treaty and in articles eighty-five and eighty-six of the E.E.C. Treaty largely coincide as to content.

${ }^{22 \pm} 26$ Stat. 209 (I890), as amended, I5 U.S.C. $\$ \$$ I, 2 (I958).

${ }^{23}$ Art. 87:

Within a period of three years after the date of the entry into force of this Treaty, the Council, acting by means of a unanimous vote on a proposal of the Commission and after the Assembly has been consulted, shall lay down any appropriate regulations or directives with a view to the application of the principles set out in Articles 85 and 86.

If such provisions have not been adopted within the above-mentioned time-limit, they shall be laid down by the Council acting by means of a qualified majority vote on a proposal of the Commission and after the Assembly has been' consulted.

2. The provisions referred to in paragraph I shall be designed, in particular:

(a) to ensure observance, by the institution of fines or penalties, of the prohibitions referred to in Article 85, paragraph $\mathrm{I}$, and in Article 86;

(b) to determine the particulars of the application of Article 85 , paragraph 3 , taking due account of the need, on the one hand, of ensuring effective supervision and, on the other hand, of simplifying administrative control to the greatest possible extent;

(c) to specify, where necessary, the scope of application in the various economic sectors of the provisions contained in Articles 85 and 86;

(d) to define the respective responsibilities of the Commission and of the Court of Justice in the application of the provisions referred to in this paragraph; and

(e) to define the relations between, on the one hand, municipal law and, on the other hand, the provisions contained in this Section or adopted in application of this Article.

${ }^{23 a}$ The draft of the first implementing regulation which since January, 1961, has been in committee of the European Parliament (E.E.C. Treaty art. 137), contains transition provisions in its arts. 5 and 6. Cf. German text, [r960] Wirtschaft und Wetrbewerb 856 [hereinafter cited as WuW], French T'cxi [196r] Revue du Marchit Commun i6. (I959).

${ }^{24}$ Cf. E.E.C. Conmission, First General Report \$ 84 (1958), Second General Report $\$$ I15

${ }_{25}$ Cf. ibid.; Federal Cartel Office, Report 55 (I959) (German Bundestag Paper No. I795, 1960). 
Both forbid any agreement between enterprises, any decisions by associations of enterprises, and any concerted practices that have as their object the prevention, restriction, or distortion of competition within the Common Market. In prohibiting concerted actions, both Treaties follow the example of American antitrust legislation. This term, so far unknown to European lawyers, is interpreted to mean that the prohibition is intended to cover any joint action by several enterprises in distortion of competition, such action being influenced by one enterprise or an association of enterprises, without, however, those concerned entering into legal engagements or commitments. $^{26}$ The interpretation and application of this concept will probably give rise to as much dispute in European practice as it has in America.

The essential difference between the provisions in the two Treaties lies in the fact that the E.E.C. Treaty forbids cartel practices only to the extent that they are likely to impede trade between Member States. The prohibition in the E.C.S.C. Treaty, on the other hand, applies also to cartels of which the activities are limited to one Member State. The E.E.C. Treaty, which applies to all trade and industry with the exception of coal and steel products, leaves it to the Member States to decide how far they wish to go in combatting cartel arrangements that are of no importance to trade between Member States.

The (unofficial) English version of article eighty-five says "which are likely to affect"; this agrees with the official French text, which says "sont susceptibles d'affecter." The equally authentic texts in the three other official languages of the Community ${ }^{27}$ contain words that, in English, would have to be rendered by "harmfully affect." 2 This narrower interpretation would seem to be more in line with the purpose behind the prohibitive clauses. ${ }^{29}$ In its comments on a cartel arrangement between German coal and fuel oil producers, the Commission has interpreted the provision in that sense by not objecting to a licence issued under German law ${ }^{30}$ because the arrangement concerned would not have any disadvantageous effect on trade between Member States. ${ }^{31}$

Moreover, it is to be assumed that the limitation of the prohibition to cases in which trade between Member States is jeopardized will lose much of its importance

\footnotetext{
${ }^{20}$ WOHLFARHT ET AL., op. cit. stipta note 3, art. 85 n.3; vON DER GROEBEN \& vON BOECKH, op. cit. supra note 3 , art. 85 n.2.

${ }^{27}$ E.E.C. Treaty art. 248.

${ }^{2 s}$ German text:

"zu beeinträchtigen geeignet sind"

Italian text:

"che possano pregindicare"

Dutch text:

"ongunstig kunnen beinvloeden"

${ }^{20}$ But see WohlfarHT eT Al., op. cit. supra note 3, art. 85 n.4.

${ }^{30}$ The licence was based on the Restriction of Competition (Prevention) Act (GWB) $\S 8$, July 27, 1957, [1957] I Bundesgesetzblatt 1081 (Ger. Fed. Rep.), under which the Federal Minister of Economics may authorize a cartel if, by way of an exception, the restriction of competition is necessary for predominant economic and general reasons. [1959] WvW 385. This cartel has since then dissolved itself.

${ }^{31}$ Verloren van Themant, Some Problexss of Competition in the Common Market (r959), quoted by NeBoLsiNe, op. cit. supra note 20, at I9.
} 
as the Common Market progresses. During the transition period, customs duties and quantitative restrictions continue amongst the Member States in respect of many goods; they will, however, be completely eliminated by the end of the transition period, $^{32}$ so that trade between the Member States will increase-which is the very objective of the Treaty.

In those fields in which the E.C.S.C. Treaty applies, especially in the coal market, conditions of competition differ substantially from those obtaining in the remainder of the Common Market. ${ }^{33}$ These differences are reflected in several provisions in the E.C.S.C. Treaty that have a certain influence on the rules of competition. For instance, the institutions of the E.C.S.C. are to ensure that the Common Market is regularly supplied, while taking into account the needs of third countries; ${ }^{34}$ they are also to assure to all consumers in comparable positions within the Common Market equal access to the sources of production. ${ }^{35}$ The E.C.S.C. Treaty then goes on to prohibit measures or practices discriminating among producers, among buyers or among consumers, especially as concerns prices and delivery terms. ${ }^{36}$ Finally, the E.C.S.C. Treaty contains explicit rules on the introduction of production quotas should the Community be faced with a serious shortage of certain products. ${ }^{87}$

These provisions reflect the anxieties that were felt on the subject of coal shortage when the Treaty was being worked out in 1951. It is now nearly three years since the situation in the energy market has undergone a fundamental change, because while coal production has risen, coal has been facing keen competition from fuel oil. The High Authority has been compelled to make use of a safeguard provision in the Treaty $^{38}$ in order to restrict coal imports from other Member States to Belgium. ${ }^{38}$ Apart from this, competition in the Common Market for coal is limited by the fact that imports into France are handled by a state agency. ${ }^{40}$

${ }^{32}$ Under E.E.C. Treaty art. 8(x), the transition period covers 12 years from the entry into effect of the Treaty (Jan. I, I958). In accordance with the provisions of art. 8, it can be extended or shortencd. Under the decisions of the Council dated May 12, 1960, on bringing forward the dates for the abolition of customs duties and quantitative restrictions within the Community, [1960] Journal Orficiel DEs Communantes Europeennes 1217 [hereinafter referred to as Journal Officiel], it is to be expected that the second and third stages of the transition period will be reduced in accordance with art. 8(5).

${ }^{83}$ See Heinrich Kronstein in his lecture Die Bedeutung der Wettbesverbstegeln im Gesamtrahmen des Montan-Vertrags und des Vertrags ïber die Europäische Wirtschaftsgemeinschaft, to the International Conference on Cartel Law, in Frankfurt/Main, on June 8, 1960.

${ }^{34}$ E.C.S.C. Treaty art. $3 a$.

${ }^{85}$ Id. art. $3 \mathrm{~b}$.

${ }^{38} I d$. arts. $4 \mathrm{~b}, 6 \mathrm{o}$.

${ }^{87}$ Id. art. 59.

${ }^{88}$ Id. art. $37(\mathrm{I})$.

30 Decision of the High Authority No. 46/59, Dec. 23, 1959, [1959] Journal Opriciel I327, as amended by Dec. No. I/60, Jan. I8, I960, [1960] Journal OfFiciel I03, No. 24/60, Dec. 7, 1960 [1960] Journal Officiei 1534, and No. 25/60, Dec. 20, 1960 [1960] Journal Officiel 1915. Two German coal-mining enterprises have, under E.C.S.C. Treaty art. 33, brought a suit of nullity against the first decision before the Court of Justice. Cf. [1960] Journal Officiel 546.

10 Association Technique de l'Importation Charbonnière. The High Authority regarded this institution as a restriction, inadmissible under the Treaty, of the access of French dealers to the coal producers of other Community countries. The French Government which had appealed against the relevant Decision of 
On the other hand, the rules of competition laid down in the E.E.C. Treaty have the unrestricted objective to set up a system that will protect competition within the Common Market from distortion. ${ }^{41}$ For this reason, the E.E.C. Treaty contains neither any provisions to meet conditions of shortage, nor any general prohibition of discrimination.

The E.E.C. Treaty lists a number of agreements, decisions, and concerted practices as being prohibited. ${ }^{42}$ This enumeration is not exhaustive and is merely intended to furnish examples of particularly flagrant types of distortion of competition. Therefore, if the prohibition provision is to be applied, the general conditions set for the prohibition must be fulfilled (likelihood of trade between Member States being impaired, or the prevention, restriction, or distortion of competition within the Common Market).

In the first place, the direct or indirect fixing of purchase or selling prices, or of any other trading conditions is forbidden. Clearly, any concerted fixing of prices will prevent competition in a particularly important field. Not only the so-called "horizontal price agreements" are forbidden-i.e., amongst manufacturers of the same type of goods-but also the so-called "vertical" price fixing agreements-e.g., between producers and distributors of a commodity. ${ }^{\mathbf{4 3}}$

Secondly, the limitation or control of production, markets, technical development, or investment is forbidden. Agreements of this nature not only impede competition, but are also incompatible with the Treaty objective, which is to bring about expansion of trade and a speedy increase in standards of living.

Market sharing or the sharing of sources of supply is also a danger to the abovementioned Treaty objective and is likewise prohibited. The beneficial effects on trade between the Member States to be obtained from the removal of customs duties and quantitative restrictions would be undone if enterprises in the various States were to conclude market-sharing agreements.

The application, to parties to transactions, of unequal terms in respect of equivalent supplies is prohibited under article eighty-five of the E.E.C. Treaty only to the extent that such parties are thereby placed at a competitive disadvantage. This so-called prohibition of discrimination, therefore, does not go so far as that of the E.C.S.C. Treaty, which quite generally prohibits any discrimination. ${ }^{44}$ Under article eighty-five, a producer is not prevented from applying unequal terms to customers who are not in competition with one another.

the High Authority of Dec. I8, 1957, has finally accepted such modifications of that institution as to render it compatible with the Treaty. The case has therefore been settled without trial. See [x96r] JouRNAL OFFICIEL 575 .

${ }^{4}$ E.E.C. Treaty art. $3 f$. The chapter on rules governing competition is applicable to the production of and trade in agricultural products only to the extent determined by the Council, however, due account being taken of the objectives mentioned in art. 39 . Id. arts. 39 and 42 .

${ }^{12}$ Id. art. 85 (I) (a)-(c); cf. supra note 20 .

18 Wohlfarht ET Al., op. cit. supra note 3, art. 85 n.6; Guenther, [1957] WuW 280, Oberlandesgericht Düsseldorf, [1958] BB IIIo.

"E.C.S.C. Treaty art. 4 b. Under art. 7, only any discrimination on the grounds of nationality is prohibited within the field of application of the Treaty and without prejudice to the special provisions menioned therein. 
The last example of prohibited measures listed in article eighty-five is the subjecting of the conclusion of a contract to the acceptance, by a party, of additional supplies that, either by their nature or according to commercial usage, have no connection with the subject of such contract. In other words, the manufacturers of, say, some new kind of textile machine would not be permitted to conclude a contract under which they would supply this new type of machine on condition only that their customers at the same time purchase a certain other machine, the performance of which was in no way connected with the former.

Naturally, the assessment of such cases depends largely on the individual circumstances and on conditions obtaining in the various industries, so that it will hardly be possible to lay down any exact rules.

II

\section{Exemption}

The strict prohibition contained in article eighty-five is mitigated in that under certain conditions it may be declared inapplicable in the case of otherwise prohibited agreements, decisions or concerted practices.

However, the conditions under which exemption may be granted are strict. In the first place, it is necessary that any such agreement must contribute to the production or to the distribution of goods, or to the promotion of technical or economic progress while reserving to users an equitable share in the profit resulting therefrom. It will, however, have to be assumed that the benefits from which consumers are to profit need not necessarily be expressed in terms of money, but could also consist in the improvement of service. ${ }^{45}$ In addition to these two positive conditions of exemption, the Treaty also sets two negative conditions by laying down that no restrictions not indispensable to the attainment of these objectives must be imposed on the enterprises-that is to say no restrictions not indispensable to the improvement of supply or the promotion of technical or economic progress. Nor must enterprises be enabled to eliminate competition in respect of a substantial proportion of the goods concerned. In practice, this will give rise to many problems, which are likely to play a part when the regulation laying down details for the implementation of article $85(3)$ is issued in accordance with article eightyseven.

On the whole, the conditions set under article $85(3)$ for the exemption of the so-called "good" cartels are more stringent than the provisions applicable in any one of the six Member States.

The E.C.S.C. Treaty, too, contains an authorization provision for certain cartel agreements. ${ }^{46}$ These must be agreements to specialize in the production of or to engage in the joint buying or selling of specified products, or agreements strictly analogous to those in their nature or effects. Agreements of another kind-as,

${ }^{45}$ Guenther, [1957] WuW 281.

${ }^{20}$ E.C.S.C. Treaty art. $65(2)$; cf. supra note $\mathrm{II}$. 
for instance, an agreed sharing of sales markets or quantities of supply-cannot be authorized. For the rest, the conditions of authorization are similar to those of the E.E.C. Treaty. ${ }^{47}$

Under the E.E.C. Treaty, the authorities of the Member States shall, until the entry into force of the provisions adopted in application of article eighty-seven, rule upon the admissibility of agreements, decisions, and concerted practices under article 85 (3) of the Treaty. ${ }^{48}$ At present, therefore, the Commission is not charged with granting exemptions, and so has acquired no practical experience to date with such exemptions. ${ }^{48 \mathrm{a}}$

In the E.C.S.C., 209 proceedings had been taken under article sixty-five by the beginning of 1960 -about half of them upon application, half of them ex officio. In II 6 cases, it has been found that article sixty-five was not applicable. Prohibitions were issued in four cases, and in eight, the cartel concerned was dissolved voluntarily; twenty-seven agreements were authorized. The problem of Ruhr-coal sales organizations is of particular importance. ${ }^{49}$

\section{III}

\section{INFRINGEMENTS}

Agreements or decisions forbidden under article $6_{5}$ (I) of the E.C.S.C. Treaty are null and void; they cannot be pleaded in defense before any court in the Member States. ${ }^{50}$

The E.E.C. Treaty also lays down that agreements or decisions forbidden under its article eighty-five shall be null and void. ${ }^{51}$ The wording of this provision indicates that this nullity is a direct consequence of the Treaty, so that a decision by

${ }^{17}$ E.E.C. Treaty art. $85(3)$, which specifies that the provisions of art. $85(\mathrm{I})$ may be declared inapplicable to classes of agreements, decisions, or concerted practices; cf. supra note 20.

${ }^{6}$ E.E.C. Treaty art. 88.

t8a The draft of the first implementing regulation (supra note 23a) provides the exclusive authority of the Commission for granting exceptions (art. 2(2)).

${ }^{40}$ This problem has been before the High Authority of the E.C.S.C. for several years. By a Decision of June 22, 1960, the High Authority rejected an application on the part of the Ruhr coal producers for the authorization of a single sales cartel for Ruhr coal, at the same time permitting them to continue, for the time being, with the present system based on Decision No. $17 / 59$ of Dec. r8, 1959, authorizing sales by three sales companies and the maintenance of one joint office by these companies. [1959] JouRnal OfFiciel 279. Without the Decision of June 22, I960, this permit would have expired on June 30,1960 . In the opinion of the High Authority, the sales cartel could not be authorized because it would have enabled the producers to determine prices on a substantial section of the coal market. According to the calculations of the High Authority, the share of Ruhr coal in the Common Market is more than $33 \%(49,500,000$ tons out of a total consumption of $146,000,000$ tons). Bopol Boerner, Die Marktbeherrschung im Kartell.recht der Montanunion UND die Ruhr-komile 27-29 (1960), however, calculates that the Ruhr coal producers planning to join the sales cartel supply no more than $11.37 \%$ of the primary energy consumed in the Common Market. In his calculation, however, Boerner includes all other sources of energy (lignite, liquid fuels, natural gas, water-power). The question, answered in the negative by the High Authority, whether the significance of other sources of energy can be taken into account when calculating the market share in accordance with E.C.S.C. Treaty art. $6_{5}(\mathrm{a})$, is the subject of a suit that the Ruhr coal-producers have brought against the High Authority and which in May, 196r, was still pending before the Court of Justice (Affair No. $13 / 60$ ).

${ }^{00}$ E.C.S.C. Treaty art. $65(4)$.

${ }^{51}$ E.E.C. Treaty art. $85(2)$. 
an authority in one of the Member States would be of no more than a declaratory nature. According to another school of thought, article $85(2)$ is to be interpreted as meaning that nullity would result only from the authority having found that an infringement of article $85(\mathrm{r})$ had occurred. ${ }^{52}$ The Commission has refrained from commenting upon this problem, because a decision on it is not essential for the evolution and implementation of the cartel policy of the Communities. The determination of the date from which onward the agreements or decisions prohibited under the Treaty become null and void is of importance mainly for the interrelation of the parties to any such cartel agreement, but not for any outsiders with whom the members of the cartel have entered into transactions. The Commission believes that the decision in this matter should be left to the competent courts, all the more since the Commission itself would not be able to make a binding declaration one way or the other. ${ }^{53}$

\section{IV}

\section{Market-Dominattng Posttions and Monopolies}

Whereas the cartel prohibition rules in the two Treaties coincide on many points, their provisions on monopolies differ in essence. ${ }^{54}$

Under the E.C.S.C. Treaty, any concentration of enterprises of which at least one is engaged in production in the field of coal and steel within the meaning of article eighty ${ }^{55}$ is subject to prior authorization by the High Authority. Where a concentration has been concluded that has not been authorized and that cannot be authorized retrospectively, the High Authority will exercise its powers to ensure the separation of the enterprises thus concentrated and to restore their independence.

The complicated procedure laid down in article 66(5) shows the difference between the criteria for article sixty-five and article sixty-six: a concentration cannot simply be "revoked" or regarded as "null and void."

Articles sixty-five and sixty-six differ further in that article sixty-six is concerned with "transactions" and not with agreements intended to have continuing operative effect. Therefore, article sixty-six applies only to transactions that occur after the entry into force of the Treaty. Any prior concentrations-and also enterprises that obtain a market-dominating position without having entered into any transaction that is subject to authorization-are merely placed under supervision intended to prevent any abuse of their power in the market. ${ }^{50}$

All transactions leading to the concentration of several enterprises are subject to

62 The Netherlands Regulation under the E.E.C. Treaty art. 88, Dec. 5, 1957, [1957] NetherLANDS OfFicial GazetTE 1070, is based on this view.

${ }^{68}$ Cf. E.E.C. Commission, Second Generar Report 87 (German version) (1959); Federal Cartel OFFICE, op. cit. supra note 25, at 56. But see, for divergent opinion, WoHLFarht ET AL., op. cit. supro note 3 , art. 88 n.4c.

s\& E.C.S.C. Treaty art. 66; cf. supra note 12; E.E.C. Treaty, art. 86; cf. supra note 21.

${ }^{85} C f$. supra note 13 and accompanying text.

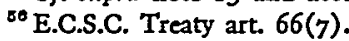


authorization. "Concentration" is to be understood as meaning not only fusion, but any condition in which several enterprises come under a unified control. Article sixty-six quotes several examples of such transactions, amongst them the acquisition of shares or assets, contracts, or any other means of control. The concept of control, which thus is of decisive importance for the criteria governing concentration-the condition brought about as a result of the transaction-has been defined in greater detail by an ordinance of the High Authority. ${ }^{57}$

The concept covers horizontal concentrations-i.e., concentrations of enterprises on the same level of production and in the same economic category-as well as vertical concentrations in which the end product of one enterprise is the basic product of another. As stated above, it is sufficient if one of the enterprises involved falls within the definition given in the Treaty; therefore, a concentration between a steelworks and a shipping line or a finance company is subject to authorization.

Nor does it make any difference whether a concentration is brought about directly or indirectly. If an enterprise $A$ already controls enterprises $B$ and $C$, and enterprise $X$ already controls enterprises $Y$ and $Z$, a concentration of $A$ and $X$ is a concentration of all the enterprises named, so that the market position of the whole complex of enterprises must be considered.

The requirement of prior authorization is to give the High Authority control over all cases of concentration and to enable it to prevent any too far-reaching concentration of economic power, which would considerably impede competition within the Common Market. Under an authorization contained in the Treaty, ${ }^{58}$ the High Authority has, with the approval of the Council of Ministers, listed in an ordinance ${ }^{59}$ a number of concentrations not requiring authorization, since they are not likely to give rise to a major distortion of competition within the Common Market.

Where a concentration has occurred without prior authorization having been obtained, the High Authority can grant such authorization retrospectively, but makes this subject to the payment of a fine. ${ }^{60}$ Where a concentration has occurred that is not eligible for authorization, the High Authority, in rendering a decision denouncing this concentration as illegal, orders the above mentioned deconcentration procedure to be initiated. ${ }^{01}$

In the field of concentrations, the High Authority has so far dealt with 136 cases (seventy-four upon application and sixty-two ex officio). In fifty-five cases, it was found that no concentration within the meaning of article sixty-six had occurred; in twelve cases, the concentrations had already existed before the entry into force of the Treaty, so that article sixty-six does not apply; four cases fell within the

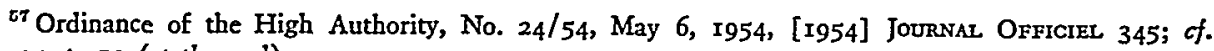
supra note 12 (at the end).

${ }^{t 8}$ E.C.S.C. Treaty art. 66(3).

${ }^{80}$ Ordinance of the High Authority No. 25/54, May 6, I954, [1954] Journal OfFicres 346, in the version of Decision of the High Authority No. 28/54, May 26, 1954, id. at 38x.

${ }^{\circ 0}$ E.C.S.C. Treaty art. $66(6)$.

ox Id. art. 66(5).
} 
exemption ordinance; ${ }^{62}$ thirty-eight concentrations were authorized, one in retrospect. The remaining cases are still under consideration. ${ }^{03}$

In addition to the prior control of concentration, the E.C.S.C. Treaty also provides for the control of market-dominating enterprises. One or several enterprises will have to be regarded as dominating the market ${ }^{64}$ if they are not subject to genuine competition-at least in respect of certain goods or services. Such a position can come about:

a. as a result of a concentration already in effect when the E.C.S.C. Treaty came into force;

b. through the evolution of a concentration of enterprises authorized by the High Authority; or

c. through an enterprise growing and acquiring unusual importance-perhaps because of some exceptional technical achievement.

If the High Authority finds that such a market-dominating enterprise uses its position for purposes incompatible with the Treaty, it will address the appropriate recommendations to such enterprise. ${ }^{05}$ If these recommendations are not satisfactorily complied with within a reasonable period, the High Authority is empowered to take very far-reaching measures ${ }^{6 B}$ after consultation with the Government concerned.

The E.E.C. Treaty does not provide any prior control of concentrations, but only prohibits the abuse of a dominant position within the Common Market, or within a substantial part of it, by one or more enterprises to the extent to which trade between Member States may be impaired thereby.

Like the cartel prohibition in article eighty-five, the prohibition of the abuse of a dominant position within the Common Market applies only to the extent that such

${ }^{82}$ Cf. supra note 59.

${ }^{68}$ It should be noted that within the E.C.S.C. 35 enterprises account for $80 \%$ of steel production, the largest of these enterprises being responsible for $6 \%$; whereas in the United States, no more than 10 cnterprises share $80 \%$ of steel production, two of them accounting for $45 \%$. If the High Authority had authorized the merger between August-Thyssen-Huette-AG. and the Phoenix-Rhcinrohr-AG. planned at the beginning of 1960 (the applieants have withdrawn their request because they were not prepared to accept certain conditions set by the High Authority), the new enterprise resulting from this fusion would, with an annual capacity of more than 5,000,000 tons, have become by far the largest within the E.C.S.C. By American standards, an enterprise of that magnitude is, however, in no way remarkable. Cf. Peter Bart, Control Dispute Halts Bonn Steel Merger, N.Y. Times, May 8, 1960, $\$ 3$, p. I, cols. I-4, p. I3, cols. $2-3$.

${ }^{\circ}$ Cf. Restriction of Competition (Prevention) Act (GWB) $\$ 22(x)$, July 27, 1957, [1957] I Bundesgesetzblatt 108I (Ger. Fed. Rep.). Under the Belgian Law on Protection Against the Abuse of Economic Power $\S I$, May 27, I960, [1960] Moniteur Belge 4674 , economic power is the ability of a natural person or a body corporate, or a group of such persons acting in concert, to excrt, by means of industrial, commercial, agricultural, or financial activities, a preponderant influence on supplies to the commodity or capital market, or on the price or the quality of a commodity or a service.

${ }^{05}$ E.C.S.C. Treaty art. $66(7)$. Under E.C.S.C. Treaty art. $14(3)$, recommendations by the High Authority shall be binding with respect to the objectives that they specify, but shall leave to those to whom they are directed the choice of appropriate means for attaining these objectives. They are, therefore, similar to the directives issued under E.E.C. Treaty art. I89, which, however, can be addressed to Member States only. Cf. supra note 19. Recommendations issued under the E.E.C. Treaty are not binding. E.E.C. Treaty art. I89(5).

${ }^{60}$ Cf. E.C.S.C. Treaty art. 66(7) (for full text, see stupra note 12). The High Authority has not, so far, availed itself of these powers. 
abuse may impair the trade between Member States. The Treaty, therefore, is not concerned with monopolies of only local effect and, accordingly, leaves it to the Member States whether or not they wish to tolerate such monopolies.

As article eighty-five does in the case of the prohibition of cartels, so articleeighty-six recites a number of particularly characteristic examples of improper advantages taken of a dominant position. They include the direct or indirect imposition of any inequitable purchase or selling prices or any other inequitable: trading conditions; the limitation of production, markets, or technical development to the prejudice of consumers; the application to parties to transactions of unequal terms in respect of equivalent supplies-as in the case of the cartel prohibition, to the extent that thereby such parties are placed at a competitive disadvantage; and: finally, the subjecting of the conclusion of a contract to the acceptance, by a party, of additional supplies that, either by their nature or according to commerciale usage, have no connection with the subject of such contract. This latter example represents a particularly characteristic and, at the same time, dangerous type of theabuse of monopoly power.

In principle, the prohibition provisions of both Treaties apply to all enterprises, irrespective of whether they are privately or publicly owned. In the E.E.C.. Treaty, however, account had to be taken of the fact that it covers enterprises charged with the management of services of general economic interest, and that in some Member States, there exist fiscal monopolies that, by the sale of commodities, provide revenue for the State. ${ }^{67}$

Such enterprises are subject to the Treaty rules on competition to the extent only that the application thereof does not obstruct the de jure or de facto fulfillment. of the specific tasks entrusted to them. ${ }^{68}$ The public utilities will have to be regarded. as the main enterprises charged with the management of services of general economic: interest, since-by concession-they supply the population with essential commodities, such as power, gas, and water. In the case of such enterprises, market sharing, for instance, is a regular necessity, because it would be technically and. economically unreasonable if, say, several electrical power companies were to. endeavor to supply consumers in the same area. In granting enterprises of this. nature exemption from the rule, the criterion is not whether they are privately or publicly owned, but solely that they must be charged with the management of: services of general economic interest.

The same exemption holds good for fiscal monopolies to the extent that the: application of the rules of competition would prevent them from fulfilling theirspecial function. Article eighty-six, therefore, does not provide any basis for charging the French and Italian tobacco monopolies with imposing inequitable selling: prices, because it is is the very function of these monopolies, by fixing their prices, to. obtain a high surplus for the benefit of the national budget. The exception made

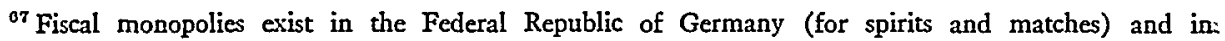
France and Italy. The tobacco monopolies in the latter two countries are of outstanding importance.

${ }^{88}$ E.E.C. Treaty arts. 85-94. Cf. supra notes I5-17.
} 
by the Treaty in favor of enterprises charged with the management of services of general economic interest and of enterprises having the character of a fiscal monopoly is restricted by the stipulation that development of trade must not be affected to such a degree as would be contrary to the interests of the Community. Under this provision, it would not be proper for the tobacco monopolies to refuse to acquire and sell tobacco goods from other Member States, because they can well fulfill their function of providing national revenue through their monopoly by selling, at the appropriate prices, tobacco goods produced in other Member States. On the other hand, these monopoly administrations, which run their own factories, can hardly be expected to close these down in order to purchase and sell produce from the other Member States. The problems connected with the implementation of this provision are at present the subject of negotiations between the Commission and the Governments concerned.

The existing national trading monopolies must be gradually so modified by the Member States that at the end of the transition period, ${ }^{60}$ all discrimination in the conditions governing supplies and sales between the nationals of the Member States will have been abolished.

\section{COMPETENCE}

Under the E.C.S.C. Treaty, the High Authority is exclusively competent for the implementation of the rules on competition; in certain circumstances only, must it consult the Governments of the Member States. ${ }^{70}$

Under the E.E.C. Treaty, on the other hand, there exists concurrent competence between the Commission and the authorities of the Member States-at least until the implementing regulations under article eighty-seven are issued. ${ }^{11}$ The Treaty provides that until the entry into force of the implementing regulations, the authorities of the Member States shall, in accordance with their respective municipal law and with the provisions of articles eighty-five and eighty-six, rule upon the admissibility of agreements, decisions, and concerted practices and upon any improper advantage taken of a dominant position in the Common Market. ${ }^{72}$

To the extent, therefore, that lacunae will exist until the implementing regulations under article eighty-seven have been issued, the Treaty refers to the municipal law of the Member States. ${ }^{73}$ This applies, in the first place, to questions of pro-

${ }^{60}$ E.E.C. Treaty art. 8. Cf. supra note 32.

${ }^{70}$ E.C.S.C. Treaty arts. $65(4) 2$ and $66(\mathrm{I})$.

${ }^{71}$ Under art. $66(2)_{4}$, the High Authority must ask for the observations of the interested Government in the case of concentrations in which at least one of the enterprises concerned is not subject to the application of E.C.S.C. Treaty art. 8o. Cf. supra note 13.

${ }^{72}$ E.E.C. Treaty art. 88.

${ }^{78}$ The following provisions are at present in force in the various Member States:

Belgium-Lois sur la Protection contre l'Abus de la Puissance Economique, May 27, I960.

Federal Republic of Germany-Gesetz gegen Wettbewerbsbeschränkungen, July 27, 1957.

France-Ordinance No. 53-704, Aug. 9, 1953, supplemented by Ordinances Nos. 58-545, June 24, 1958, and 59-1004, Aug. 17, 1959. 
cedure, but also to the settlement of matters such as the formalities governing the conclusion of agreements within the meaning of article eighty-five, the question of whether agreements or decisions are to be notified and registered, under what conditions those concerned can withdraw from cartel arrangements, and so on.

The authorities of the Member States are to apply their municipal law in accordance with articles eighty-five and eighty-six. Since these articles apply only in cases where the prohibited agreements or decisions or the abuse of a dominant position are likely to impair trade between the Member States, no problem arises where these conditions, on which the application of these articles depends, are not fulfilled. In consequence, the authorities of the Member States have to apply only their own municipal provisions to agreements that do not affect trade between the Member States. To the extent that trade between the Member States is impaired-which is likely to be the case with increasing frequency as the establishment of the Common Market progresses-the authorities of the Member States will also apply their municipal law until the implementing regulations under article eighty-seven shall have entered into force. But in doing so, they must, at the same time, take into account the principles contained in articles eighty-five and eighty-six. Where, for instance, the municipal anticartel provisions allow an exception in favor of export cartels, the authorities of the Member States may no longer grant this exception if such an export cartel is likely to impair the trade between the Member States. The provision in municipal law allowing export cartels is based on the consideration that it is of no concern to the internal market if producers of certain goods agree on the fixing of prices or the sharing of markets when exporting their produce to other countries. Since the entry into force of the E.E.C. Treaty, this point of view is no longer fully justified, since the interest of the Community is affected if an export cartel in one Member State fixes prices for exports into other Member States or if the markets in the other Member States are allocated. The authorities of the Member States may, therefore, under article eighty-eight only continue to apply their municipal provisions on the admissibility of export cartels in accordance with article eighty-five, and they may only tolerate export cartels if they export their goods into nonmember countries. ${ }^{74}$

From the inception of its work, the Commission has been charged with the function to ensure that the principles laid down in articles eighty-five and eighty-six are translated into practice. ${ }^{75}$ In fulfillment of this function, the Commission, acting either upon the request of a Member State or ex officio-e.g., on a complaint received from an enterprise aggrieved by cartel agreements or by the abuse of a dominant position-examines all those cases in which an infringement of articles eighty-five

The Netherlands-Wet Economische Mededing, July 16, I958.

In Italy and Luxembourg, no cartel legislation proper has yet been introduced. The Italian: Government submitted a draft antimonopoly law to Parliament on Nov. 28, 1959. A Luxembourg draft is being prepared.

"Wohlfarht ET AL., op. cit. supra note 3, art. 88 n.6.

${ }^{75}$ E.E.C. Treaty art. 89. 
and eighty-six is suspected. The Commission carries out such examinations in .cooperation with the competent authorities of the Member States, which are obliged to assist it. At present, the Commission is investigating a number of cases brought to its knowledge by complaints. Should the Commission find that the principles of articles eighty-five and eighty-six have been infringed, it proposes the appropriate steps to remedy the situation. As a rule, the Commission will have to address these recommendations to the enterprises concerned in the agreement. Under article eighty-nine, the Commission is not empowered to compel those concerned to cease the infringement. ${ }^{75 a}$ If the infringement is continued, the Commission will issue a reasoned decision, declaring such an infringement to exist. The Commission can, moreover, publish its decision and authorize the Member States to carry out the necessary remedies, the conditions and details of which it lays down. It is to be assumed that the publication of a Commission decision declaring that articles eightyfive and eighty-six have been infringed would have a considerable moral effect.

It is important to note that the competence vested in the Commission under article eighty-nine, in contrast to the competence of the authorities of the Member States under article eighty-eight, is not restricted to the period until the entry into effect of the implementing regulations under article eighty-seven of the Treaty. Even if these implementing regulations were completely to transfer the application of articles eighty-five and eighty-six to the authorities of the Member States, the Commission would still retain its function of ensuring that the principles contained in articles eighty-five and eighty-six are translated into practice; to this end, the Commission would continue to initiate its own investigations.

\section{VI}

\section{Appeals}

The Court of Justice of the Communities ${ }^{76}$ ensures observance of law and justice in the interpretation and application of the Treaties. ${ }^{77}$ Under article thirty-three of the E.C.S.C. Treaty, enterprises may plead for the annulment of individual decisions and recommendations affecting them, or of general decisions and recommendations that they deem to involve an abuse of power affecting them, on the grounds of lack of legal competence, major violations of procedure, violation of the Treaty or of any rule of law relating to its application, or abuse of power. However, the Court may not review the High Authority's evaluation of the situation, based on economic facts and circumstances, that led to such decisions or recommendations, except where the High Authority is alleged to have abused its powers or to have clearly misinterpreted the provisions of the Treaty or of a rule of law relating to its application. $^{78}$ An appeal to the general jurisdiction of the Court may be lodged against

${ }^{75 a}$ The draft of the first implementing regulation provides for a power in the Commission to issue decisions against enterprises or associations of enterprises (art. 8).

${ }^{70}$ See supra note 5 .

${ }^{77}$ E.C.S.C. Treaty art. 31 ; E.E.C. Treaty art. 164 ; Euratom Treaty art. 136.

${ }^{28}$ E.C.S.C. Treaty art. 33. 
the pecuniary sanctions and daily penalty payments imposed under the provisions of the Treaty. The petitioners may contest the legality of the decisions and recommendations that they are charged with violating. ${ }^{79}$

The provisions of the E.E.C. Treaty concerning appeals to the Court against Commission decisions are similar to the corresponding provisions in the E.C.S.C. Treaty. ${ }^{80}$ The E.E.C. Treaty, however, does not provide any restrictions of the Court's review so far as the evaluation of the situation based on economic facts and circumstances is concerned.

So far as the authorities of the Member States are called upon to implement the rules of competition laid down in the Treaty, ${ }^{81}$ appeals against their decisions must, under article eighty-eight, be lodged in accordance with the municipal law of the individual Member State. So far as the competent courts in the Member States must, in so doing, take action predicated on an interpretation of the rules of competition laid down in the Treaty, the Court of Justice of the Communities is competent to make preliminary decisions. Under article $\mathrm{x} 77$, any court in one of the Member States may place any doubt about the interpretation of the Treaty before the Court of Justice, if it considers that its judgment depends on a preliminary decision on this question. Where any such question is raised in a case pending before a domestic court from whose decisions no appeal lies under municipal law, such court is obliged to refer the matter to the Court of Justice. ${ }^{82}$ Article $x 77$ thus ensures uniform interpretation of the Treaty and prevents differences in the conditions of competition from existing in the various Member States as a result of varying interpretations by the authorities or courts in them.

\section{SuMmary}

Both the E.C.S.C. Treaty and the E.E.C. Treaty contain rules of competition in respect of enterprises. Both Treaties prohibit agreements among enterprises, decisions by associations of enterprises, and any concerted practices leading to a prevention, restriction, or distortion of competition within the Common Market.

The prohibition contained in the E.C.S.C. Treaty applies to all agreements, decisions, and concerted practices of enterprises engaged in the production or distribution in the field of coal and steel (with the exception of sales to domestic consumers or craft industries). The E.E.C. Treaty, which applies to all other branches of the economy, prohibits cartel practices only to the extent that they are likely to impede trade among the Member States.

Both Treaties provide that agreements, decisions, or concerted practices may be authorized under relatively strict conditions.

${ }^{70}$ Id art. $36(3)$.

${ }^{80}$ E.E.C. Treaty arts. 172 and $\mathrm{r} 73$; Euratom Treaty arts. $\mathrm{x} 44$ and 146 .

${ }^{82}$ E.E.C. Treaty art. 88 . Cf. supra note 72 and accompanying text.

${ }^{89}$ A somewhat similar procedure is foreseen by the Basic Law of the Federal Republic of Germany, art. 100(I), May 23, 1949, [1949] I Bundesgesetblatt I (Ger. Fed. Rep.). This provision obliges the courts to ask for a preliminary decision of the Federal Constitutional Court when they have doubt as to the compatibility of a Federal or State law with the Basic Law and when their judgment depends on the validity of such a law. 
The E.C.S.C. Treaty makes concentrations of enterprises subject to prior approval by the High Authority if at least one of the enterprises concerned is a coal and steel enterprise. The E.E.C. Treaty, on the other hand, prescribes no prior control of concentrations, but merely prohibits the abuse of a dominant position in the Common Market, and that only if it is likely to impede trade among the Member States.

Under the E.C.S.C. Treaty, the High Authority is exclusively competent for the implementation of the rules of competition. Under the E.E.C. Treaty, these are exclusively applicable by the authorities of the Member States until implementing regulations are issued; nevertheless, the Commission is already charged with ensuring that these rules are translated into practice. The implementing regulations to be issued can confer unto the Commission a further reaching competence in the application of the rules on competition laid down in the Treaty. 